\title{
New perspectives on vitamin $D$ food fortification based on a modeling of 25(OH)D concentrations
}

\author{
Jonathan Brown ${ }^{1 \dagger}$, Arne Sandmann ${ }^{1 \dagger}$, Anita Ignatius $^{2}$, Michael Amling ${ }^{1 *}$ and Florian Barvencik ${ }^{1}$
}

\begin{abstract}
Background: In Germany, vitamin D intake from food and synthesis in the skin is low, which leads to low 25(OH)D serum concentrations. In contrast to many other countries, general vitamin D food fortification is still prohibited in Germany, although the European Commission published a regulatory framework to harmonize addition of vitamins to foods. Thus the purpose of our study was to develop a vitamin D fortification model, taking into account all vitamin D sources with the goal to fulfill requirements of intake recommendations or preferable $25(\mathrm{OH}) \mathrm{D}$ serum concentrations. Finally, the aim was to assess the suitability of different carriers and associated risks.

Methods: We developed a mathematical bottom-up model of $25(\mathrm{OH}) \mathrm{D}$ serum concentrations based on data about vitamin D sources of the German population such as sunlight, food and supplements for all federal states taking seasonal and geographical variations into account. We used this model to calculate the optimal fortification levels of different vitamin D carriers in two approaches. First we calculated required fortification levels based on fixed intake recommendations from e.g. the IOM or the DGE and second based on achieving certain 25(OH)D serum concentrations.

Results: To lift 25(OH)D serum concentration in Germany to $75 \mathrm{nmol} / \mathrm{L}$, e.g. $100 \mathrm{~g}$ bread has to be fortified with $11.3 \mu \mathrm{g}$ during winter, resulting in a daily vitamin D intake of $23.7 \mu \mathrm{g}$. Bread seems to be a suitable carrier for base supply. However, overdose risk with a single fortified product is higher than the risk with several fortified carriers.
\end{abstract}

Conclusions: With the model in hand, it is possible to conceive vitamin D fortification strategies for different foodstuffs and model its impact on 25(OH)D serum concentrations.

Keywords: Vitamin D, Vitamin D deficiency, Vitamin D food fortification

\section{Introduction}

Sufficient vitamin D intake as well as adequate vitamin $\mathrm{D}$ synthesis in the skin is required to control calcium homeostasis a bone turnover. The effects of vitamin D on human health are diverse [1] but not yet fully investigated. However, vitamin $\mathrm{D}$ has been implicated in the risk of overall mortality [2], cancer [3-12], diabetes [13-15], musculoskeletal disorders [16], mental [17] and physical performance [18], hypertension [19], cardiovascular diseases [20], and autoimmune diseases [19,21]. Although, many benefits of vitamin D are ubiquitously known, recommended intake (RI) and more importantly upper limits (UL) have to be considered to prevent

\footnotetext{
*Correspondence: amling@uke.de

${ }^{\dagger}$ Equal contributors

${ }^{1}$ Department of Osteology and Biomechanics, University Medical Center Hamburg-Eppendorf, Martinistraße 52, D-20246 Hamburg, Germany

Full list of author information is available at the end of the article
}

adverse effects such as vitamin $\mathrm{D}$ intoxication. Intoxication may occur at $25(\mathrm{OH}) \mathrm{D}$ concentrations above $500 \mathrm{nmol} / \mathrm{L}$ [22], while $75 \mathrm{nmol} / \mathrm{L}$ are considered as adequate $[23,24]$.

In Germany, vitamin D intake from natural food sources $[25,26]$ as well as vitamin D synthesis in the skin is low [23], which subsequently leads to low $25(\mathrm{OH}) \mathrm{D}$ serum concentrations. In Germany this was once reported in a population study of Hintzpeter and coworkers [26] and is now detailed with a novel mathematical bottom-up model of 25(OH)D concentrations [27]. Building on this knowledge, the aim of our study was to develop a novel vitamin D fortification model, taking into account all vitamin $\mathrm{D}$ sources, different carrier products suitable for fortification and various fortification scenarios to fulfill requirements of risk

\section{Biomed Central}


considerations as well as both intake recommendations and 25-hydroxyvitamin D concentrations.

Earlier fortification models have been published by Flynn and co-workers [28], Rasmussen and co-workers [29] or by Hirvonen and co-workers [30]. Models from Flynn and Rasmussen consider the safe upper limit for vitamin D fortification per energy unit. While in the Flynn model only vitamin D intake from natural food sources is considered as the basis for estimating the fortification levels, the Rasmussen model also takes into account the vitamin D intake from supplements. Whereas these two models give fixed values based on equations, the Hirvonen model developed the association between the risk of exceeding the UL and the fortification level. This is important for risk managers in order to decide on the acceptable risk. Our model, however aimed to combine advantages of previous models and add another, yet unconsidered, but significant aspect to vitamin $\mathrm{D}$ fortification modeling. It includes not only food intake from natural food sources and supplemental habits, but also vitamin D synthesis in the skin. In order to allow risk considerations, we defined various fortification scenarios for different dietary intake of natural food sources $\left(5^{\text {th }}\right.$ percentile, mean and $95^{\text {th }}$ percentile). Still, we have to mention that our study does not include estimates on an individual level, as it only considers average data.

\section{Methods}

Model is based on three core dimensions

A bottom-up model of $25(\mathrm{OH}) \mathrm{D}$ serum concentrations [27] as a function of sun exposure, food and supplements predicts and considers both vitamin D sources and vitamin D status of the average population in Germany. Output values are $25(\mathrm{OH}) \mathrm{D}$ serum concentrations of an average German individual for each month of the year and for each German federal state. For detailed description of the model and its results please see "New perspectives on vitamin $\mathrm{D}$ sources in Germany based on a novel mathematical bottom-up model of 25(OH)D serum concentrations" [27].

Having a detailed understanding of the contributing factors and the resulting $25(\mathrm{OH}) \mathrm{D}$ concentrations, one can develop new perspectives on food fortification scenarios for Germany. The fortification model depicted in Figure 1 describes scenarios for a vitamin D fortification of bread, milk and juice. Zero point of each axis describes a minimum fortification scenario, while the fortification level rises with increasing distance from zero point. The maximum fortification scenario is indicated by the dotted cube. Depending on the chosen value of each axis, the size of the cube represents fortification intensity. This model does only stand for information for the average German population, but is not capable of considering fortification scenarios for individuals.

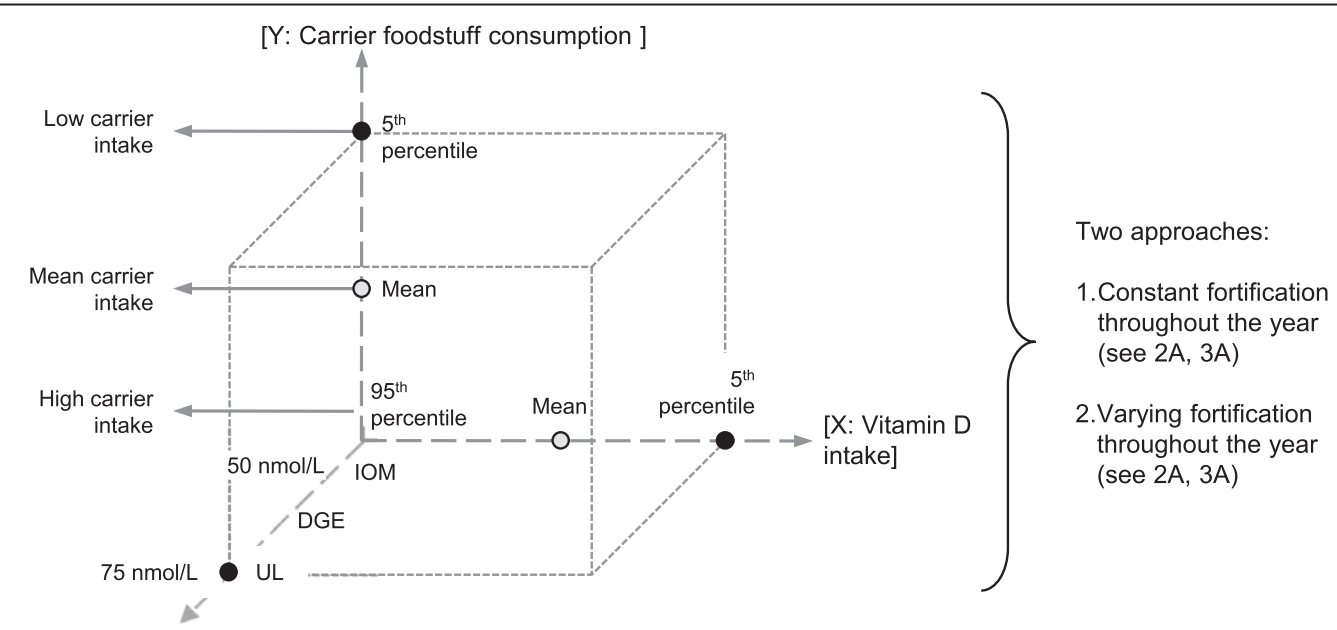

[Z: Intake recommendation or recommended $25(\mathrm{OH}) \mathrm{D}$ level]

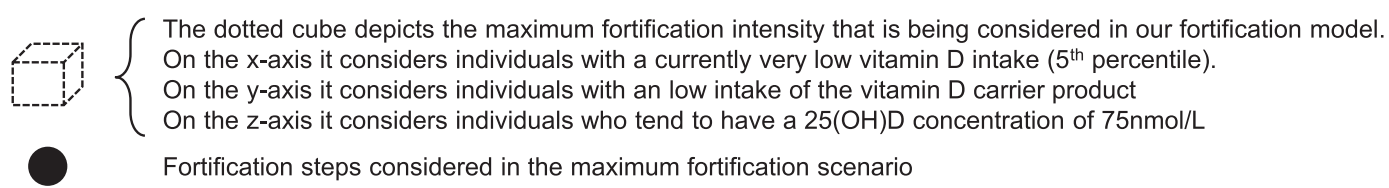

Figure 1 Logic of the vitamin D fortification model. The three axes depict the logic of each fortification intensity scenario considered in our model. The x-axis - vitamin D intake - represents daily vitamin D intake through natural food sources as well as supplements. While individuals of the $95^{\text {th }}$ (zero point) percentile already have a high vitamin D intake, individuals of the $5^{\text {th }}$ percentile (furthest from zero point) still have a low vitamin D intake. The more vitamin D an individual already consumes, the lower the calculated fortification intensity in our model. 
The $\mathrm{x}$-axis - vitamin D intake - represents daily vitamin $\mathrm{D}$ intake through natural food sources as well as supplements [27]. While individuals of the $95^{\text {th }}$ (zero point) percentile have high vitamin $\mathrm{D}$ intake, individuals of the $5^{\text {th }}$ percentile (furthest from zero point) have low vitamin $\mathrm{D}$ intake. The more vitamin $\mathrm{D}$ the population consumes on average the less the food has to be fortified.

The y-axis - carrier foodstuff consumption - plots consumption habits of the general population for foodstuffs, which this model considers to be fortified. Zero point of $\mathrm{y}$-axis belongs to the $95^{\text {th }}$ (high carrier intake scenario) percentile of food consumers who consume large quantities of considered fortified carriers and the $5^{\text {th }}$ (low carrier intake scenario) percentile, furthest from zero point, belongs to those who consume very little of respective foodstuff. The average consumption of considered foodstuff in the population is represented by the "mean carrier intake" scenario. As there are differences between men's and women's nutritional habits, in all "high carrier intake" and in all "mean carrier intake" case scenarios, higher consumption volumes and thus lower fortification levels were used for reasons of conservative considerations. In all regarded carriers, men are those who consume more than women. Only in the "low carrier intake" scenario, we used consumption quantities of those, who consume less. For all carriers considered this means women. An exemption to this is milk as in the $5^{\text {th }}$ percentile of milk consumers, men consume less than women. The "low carrier intake" ( $5^{\text {th }}$ percentile) scenario means that $95 \%$ of the individuals of the population would have an additional vitamin D intake through fortified food, which lifts their intake and thereby their $25(\mathrm{OH}) \mathrm{D}$ serum concentrations to a targeted level (z-axis).

The $\mathrm{z}$-axis - intake recommendation or recommended $25(\mathrm{OH}) \mathrm{D}$ level - describes the recommended vitamin D intake or a $25(\mathrm{OH}) \mathrm{D}$ serum concentration to achieve. Zero point of z-axis refers to individuals, who tend to meet RI values of the Institute of Medicine $(15 \mu \mathrm{g}$ per day, IOM) and thereby reach $25(\mathrm{OH}) \mathrm{D}$ serum concentrations of $50 \mathrm{nmol} / \mathrm{L}$ which is defined as the lower value for adequate circulating $25(\mathrm{OH}) \mathrm{D}$ level by the IOM [31]. For the UL we considered people older than 8 years with an upper intake limit of $100 \mu \mathrm{g}$ [31] or with a serum threshold of $75 \mathrm{nmol} / \mathrm{L}[23,24]$.

\section{Seasonally varying fortification introduced as alternative approach to constant fortification}

This model is being developed in two approaches. The first approach aims to define a constant fortification (z-axis as intake recommendation) of different carrier foodstuffs throughout the year, as is common practice. For the constant fortification model, the vitamin D serum concentration model [27] was only used in parts. That is because 25 $(\mathrm{OH}) \mathrm{D}$ serum levels are not used as calculation base, but only vitamin D intake from natural food sources plus an average vitamin D intake from vitamin D supplements. To calculate constant fortification $\left(\mathrm{f}_{\mathrm{c}}\right)$ levels of carrier foodstuff, the difference $\left(\delta_{\mathrm{i}}\right)$ between recommended vitamin D intake $\left(\mathrm{I}_{\mathrm{r}}\right)$ and actual vitamin $\mathrm{D}$ intake through natural food sources and supplements $\left(I_{a}\right)$ is divided by intake of considered food to be fortified $\left(\mathrm{F}_{\mathrm{i}}\right)$, which are bread and milk as well as juice. This model can be easily adapted to all fortifiable food sources, but we only considered the three mentioned products. The underlying rationale of choosing these foodstuffs was on the one hand the goal to choose a carrier that is consumed by most people in Germany (here bread) and to choose carriers, for which there are many fortification experiences in other countries (here milk as well as juice).

The more the population consumes considered carrier foodstuff $\left(\mathrm{F}_{\mathrm{i}}\right)$, the less will it be fortified. The higher the recommended intake levels $\left(\mathrm{I}_{\mathrm{r}}\right)$, e.g. the $20 \mu \mathrm{g}$ recommendation by the German Nutrition Society (DGE) [32], the more will the carrier be fortified. $\mathrm{f}_{\mathrm{c}}$ is calculated for all scenarios, which are determined by the different characteristics of the three axes depicted in Figure 1. The dimension of $f_{c}$ is $\mu \mathrm{g}$ per $100 \mathrm{~g}$ of considered fortified foodstuff, which is why we include the normalizing factor of 100 in the function $\mathrm{f}_{\mathrm{c}}$. For bread, only bread and rolls were considered. Pastries such as baked goods, cakes, cream pies or pizza as well as cereal and grain products were not considered here. Among the category milk we subsumed milk, milk mix drinks as well as milk products such as yoghurt or buttermilk. Juices contain all fruit juices and fruit nectars, but not vegetable juices and juice drinks such as apple juice spritzer. For detailed input parameter of the fortification model, see Table 1 [23,24,27,31-34].

$$
f_{c}=\delta_{i} \cdot \frac{100}{F_{i}}=\left(I_{r}-I_{a}\right) \cdot \frac{100}{F_{i}}
$$

The second approach aims to level 25(OH)D serum concentrations by varying the fortification amount per fortified foodstuff throughout the year (z-axis as $25(\mathrm{OH})$ $\mathrm{D}$ target level). For the varying fortification model, the vitamin D serum concentration model [27] was used as a whole. That is because $25(\mathrm{OH}) \mathrm{D}$ serum levels were used as calculation base. To calculate varying fortification levels $f_{v}$ of the different carrier foodstuffs, the difference $\left(\delta_{\mathrm{c}}\right)$ between recommended $25(\mathrm{OH}) \mathrm{D}$ levels $\left(\mathrm{L}_{\mathrm{r}}\right)$ and actual $25(\mathrm{OH}) \mathrm{D}$ levels $\left(\mathrm{L}_{\mathrm{a}}\right)$ is divided by the conversion factor $\left(\mathrm{c}_{\mathrm{f}}\right)$ as well as by intake of considered food to be fortified $\left(\mathrm{F}_{\mathrm{i}}\right)$, which are bread and milk and juice. The conversion factor (cf) was derived from O'Donnell's review on efficacy of food fortification on serum 25-hydroxyvitamin D concentrations [33]. O’Donnell included not 
Table 1 Input parameters of the model

\begin{tabular}{|c|c|c|c|}
\hline$\#$ & Parameter & Value or comment & Source \\
\hline 1 & Vitamin D serum concentration model & & \\
\hline 1.1 & $25(\mathrm{OH}) \mathrm{D}$ concentration & $\begin{array}{l}\text { Varies per month and per federal state } \\
\text { of Germany [nmol/L]; average: } 45 \mathrm{nmol} / \mathrm{L}\end{array}$ & Brown et al [27]. \\
\hline 1.2 & Vitamin D intake through food & $\begin{array}{l}\text { Varies per gender; mean average men: } 3.4 \mu \mathrm{g} \\
\text { and mean average women: } 2.8 \mu \mathrm{g} \text { per day }\end{array}$ & Brown et al [27]. \\
\hline 2 & Carrier foodstuff consumption & & \\
\hline \multirow[t]{4}{*}{2.1} & Bread & Men/Women & \multirow{4}{*}{$\begin{array}{l}\text { National Nutritional } \\
\text { Survey II [34] }\end{array}$} \\
\hline & $5^{\text {th }}$ percentile & $46 \mathrm{~g} / 43 \mathrm{~g}$ & \\
\hline & Mean intake & $180 \mathrm{~g} / 134 \mathrm{~g}$ & \\
\hline & $95^{\text {th }}$ percentile & $377 \mathrm{~g} / 270 \mathrm{~g}$ & \\
\hline \multirow[t]{4}{*}{2.2} & Milk & Men/Women & \multirow{4}{*}{$\begin{array}{l}\text { National Nutritional } \\
\text { Survey II [34] }\end{array}$} \\
\hline & $5^{\text {th }}$ percentile & $16 \mathrm{~g} / 22 \mathrm{~g}$ & \\
\hline & Mean intake & $222 \mathrm{~g} / 203 \mathrm{~g}$ & \\
\hline & $95^{\text {th }}$ percentile & $712 \mathrm{~g} / 555 \mathrm{~g}$ & \\
\hline \multirow[t]{4}{*}{2.3} & Juice & Men/Women & \multirow{4}{*}{$\begin{array}{l}\text { National Nutritional } \\
\text { Survey II [34] }\end{array}$} \\
\hline & $5^{\text {th }}$ percentile & $0 \mathrm{~g} / 0 \mathrm{~g}$ & \\
\hline & Mean intake & $270 \mathrm{~g} / 232 \mathrm{~g}$ & \\
\hline & $95^{\text {th }}$ percentile & $1,200 \mathrm{~g} / 1,000 \mathrm{~g}$ & \\
\hline 3 & Intake recommendation or $25(\mathrm{OH}) \mathrm{D}$ recommendation & & \\
\hline \multirow[t]{4}{*}{3.1} & Intake recommendation & & \\
\hline & $\mathrm{IOM}$ & $15 \mu \mathrm{g}$ & IOM [31] \\
\hline & DGE & $20 \mu \mathrm{g}$ & DGE [32] \\
\hline & Upper Limit (UL) & $100 \mu \mathrm{g}$ & $\mathrm{IOM}[31]$ \\
\hline \multirow[t]{4}{*}{ 3.2. } & Recommended 25(OH)D conc. & & \\
\hline & $\mathrm{IOM}$ & $50 \mathrm{nmol} / \mathrm{L}$ & IOM [31] \\
\hline & Bischoff-Ferrari et al., & $75 \mathrm{nmol} / \mathrm{L}$ & Bischoff-Ferrari et al [24], \\
\hline & Domarus et al. & & Domarus et al [23]. \\
\hline 4 & Others & & \\
\hline 4.1 & Conversion factor fortified food to $25(\mathrm{OH}) \mathrm{D}$ serum increase & $2.32 \mathrm{nmol} / \mathrm{L}$ per $1 \mu \mathrm{g}$ & O’Donnell [33] \\
\hline
\end{tabular}

only milk-based fortified food, but also different dairy based products, bread and orange juice, which reflects the vitamin D carrier portfolio chosen in our study. O'Donnell reported conversion factors indirectly as she mentions base and final $25(\mathrm{OH}) \mathrm{D}$ concentrations after a certain additional vitamin $\mathrm{D}$ intake. Out of 9 trials, 7 provided sufficient data for calculation of the absolute mean change from baseline in $25(\mathrm{OH}) \mathrm{D}$. We used these 7 trials for conversion factor calculation for fortified food. The normalizing factor 100 is used likewise. Actual levels $\left(\mathrm{L}_{\mathrm{a}}\right)$ are specific for each month of the year and are derived from the vitamin D serum concentration model [27].

$$
f_{v}=\delta_{c} \cdot \frac{100}{c_{f} \cdot F_{i}}=\left(L_{r}-L_{a}\right) \cdot \frac{100}{c_{f} \cdot F_{i}}
$$

To get an impression of the new ("n") 25(OH)D serum concentrations in case of vitamin D food fortification
$\left(L_{n x}\right)$ for each month " $x$ " of the year, we calculated resulting vitamin $\mathrm{D}$ concentrations as a function of actual ("a") (25)OHD concentration per month " $\mathrm{x}$ " $\left(\mathrm{L}_{\mathrm{ax}}\right)$ plus its rise due to consumption of fortified food $\left(\mathrm{F}_{\mathrm{i}}\right)$. As a monthly change of the fortification intensity is not practical we defined cluster of seasonally changing fortification levels (summer time and winter time).

$$
L_{n x}=L_{a x}+\frac{c_{f} \cdot F_{i} \cdot f_{v}}{100}
$$

\section{Software tools}

All models were calculated using Excel version 2007. Macros were programmed in Visual Basic version 6.5. Pictures were created using PowerPoint version 2007 and Think-Cell version 5.2. 
Ethics approval

This study was approved by the local ethics board of the University Medical Center Hamburg. There was no need for further ethics approval as the study is only based on publicly available data (see Table 1: Input parameters of the model). Hence there were no direct participants in our study which is why no written informed consent for participation in the study needed to be obtained.

\section{Results}

Ideal fortification levels vary by underlying conditions

The Figure 2A/B portrays the vitamin D fortification

level of $100 \mathrm{~g}$ of bread in the two approaches described

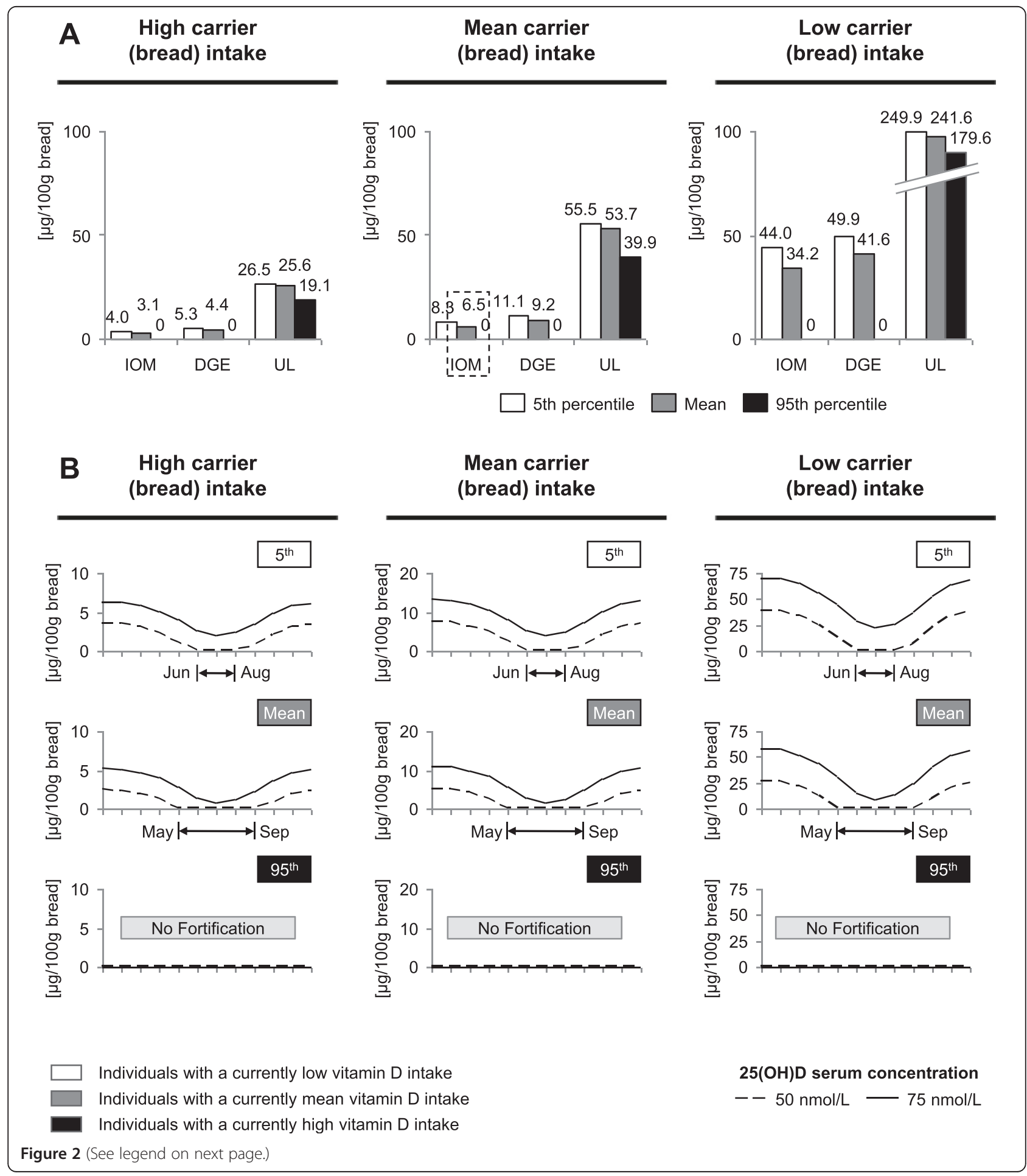


(See figure on previous page.)

Figure 2 Vitamin D fortification of bread. Figure 2 depicts fortification levels for bread that are needed to either increase an individual's vitamin D intake to a recommended level (IOM, DGE or to the UL, figure $\boldsymbol{A}$ ) or to increase an individual's $25(\mathrm{OH}) \mathrm{D}$ concentration to a preferred level $(50 \mathrm{nmol} / \mathrm{L}$ or $75 \mathrm{nmol} / \mathrm{L}$, figure $\boldsymbol{B}$ ). The three columns represent the three scenarios of individuals with different carrier intakes (here: high, mean and low bread intake). A. Fortification levels for bread to meet intake values of nutritional guidelines of the IOM, of the DGE or to reach the UL. For definition of the "high carrier intake", "mean carrier intake" and "low carrier intake" scenarios see Figure 1. Please note the break in the "low carrier intake" scenario for the UL. The x-axis depicts recommended intake levels, while y-axis shows fortification levels in $\mu \mathrm{g}$ per $100 \mathrm{~g}$ bread. White ( $5^{\text {th }}$ percentile), grey (mean intake) and black shaded ( $95^{\text {th }}$ percentile) bars reflect the current vitamin $\mathrm{D}$ intake levels (natural food sources and supplements). B. Fortification scenarios to reach concentrations of either $50 \mathrm{nmol} / \mathrm{L}$ or $75 \mathrm{nmol} / \mathrm{L}$. The $\mathrm{x}$-axis depicts varying fortification levels throughout the year, while the $\mathrm{y}$-axis shows fortification levels in $\mu \mathrm{g}$ per $100 \mathrm{~g}$ bread. The dotted line belongs to individuals who tend to reach a $25(\mathrm{OH}) \mathrm{D}$ concentration of $50 \mathrm{nmol} / \mathrm{L}$ and the solid line belongs to the $75 \mathrm{nmol} / \mathrm{L}$ goal. Below each graph, months are indicated, during which no fortification is required. White ( $5^{\text {th }}$ percentile), grey (mean intake) and black ( $95^{\text {th }}$ percentile) labeled graphs stand for the current vitamin D intake levels (natural food sources and supplements).

in Figure 1. E.g. Figure 2A "mean carrier intake-IOMmean scenario" (indicated as the dotted box in Figure 1 and Figure 2A) means that $100 \mathrm{~g}$ bread has to be constantly fortified with $6.5 \mu \mathrm{g}$ in order to provide someone who is an average bread ("mean carrier intake") and an average vitamin D consumer ("mean") with $15 \mu \mathrm{g}$ a day ("IOM"). The average bread intake is approximately $180 \mathrm{~g}$, the average vitamin D intake is $3.1 \mu \mathrm{g}$ (for both men and women). $6.5 \mu \mathrm{g}$ multiplied with 1.8 (180 g divided by normalizing factor 100) plus $3.1 \mu \mathrm{g}$ and $0.3 \mu \mathrm{g}$ of supplements (men and women averaged) is approximately $15 \mu \mathrm{g}$ (differences due to rounding). Figure $2 \mathrm{~B}$ follows the same calculation logic, but is not based on a constant fortification level, but on seasonal variations of $25(\mathrm{OH}) \mathrm{D}$ concentrations. Scenarios of Figure $2 \mathrm{~B}$ thus aim to keep vitamin serum concentrations on a constant level throughout the year. E.g. Figure 2B "mean carrier intake-75 nmol/L-mean scenario" means that in January, $100 \mathrm{~g}$ bread has to be fortified with approximately $11.3 \mu \mathrm{g}$. Someone who consumes $180 \mathrm{~g}$ bread ("mean carrier intake") and who has an average vitamin D intake ("mean") thus has a daily vitamin D intake need of approximately $23.7 \mu \mathrm{g}(20.3 \mu \mathrm{g}$ plus $3.1 \mu \mathrm{g}$ plus $0.3 \mu \mathrm{g})$ to yield a $25(\mathrm{OH}) \mathrm{D}$ concentration of $75 \mathrm{nmol} / \mathrm{L}$. We calculated fortification levels not only for bread (Figure 2A/B), but also for milk and juice, Figure 3A/B. In Figures $2 \mathrm{~B}$ and $3 \mathrm{~B}$, we indicated months, during which no fortification is required in order to guarantee targeted 25(OH)D concentrations. In case fortification levels drop below the zero level, the fortification level was set to level 0 . These months were the base for defining cluster of seasonally changing fortification levels.

\section{Effects on 25(OH)D concentration serve as basis for risk assessment}

The modeled effect of vitamin $\mathrm{D}$ food fortification on $25(\mathrm{OH}) \mathrm{D}$ serum is shown in Figure $4 \mathrm{~A}$ and Figure $4 \mathrm{~B}$. Figure 4A depicts the scenario of people who have an average vitamin D intake from food and supplements as well as an average consumption of the carrier foodstuff. The two graphs in Figure 4A are equal for all fortified foodstuffs, as our goal was to set $25(\mathrm{OH}) \mathrm{D}$ serum concentrations to the same level for each carrier product. In some months, the right graph shows no difference between old and new serum concentrations, as there is no fortification from May to September (see Figure 2B and $3 \mathrm{~B})$. For risk assessments, Figure $4 \mathrm{~B}$ aims to assess the effect of a fortification level based on average carrier intake on people with extreme dietary intake of vitamin D as well as extreme dietary intake of the carrier product. Driving factors for these extreme estimates are high vitamin D intake ( $95^{\text {th }}$ percentile) and high fortified foodstuff consumption $\left(95^{\text {th }}\right.$ percentile) for the upper limit as well as low vitamin $\mathrm{D}$ intake ( $5^{\text {th }}$ percentile) and low fortified foodstuff consumption ( $5^{\text {th }}$ percentile) for the lower limit. It becomes obvious that bread has the most stable effect on $25(\mathrm{OH}) \mathrm{D}$ serum concentrations among the three foodstuffs when estimating to the upper or to the lower limit. Considering the upper limit, the effect of fortified food overrides all other vitamin D sources. This especially holds true for milk and juice. On the other side the lower limit considerations $\left(5^{\text {th }}\right.$ percentile) show almost no change, as this group of the population consumes almost none of respective foodstuffs. The effect of different consumption habits in the general German population for these three carriers is shown in Figure 4C. It shows vitamin $\mathrm{D}$ intake multipliers due to differences between $5^{\text {th }}$ percentile intake, mean intake and $95^{\text {th }}$ percentile intake. Very prominent is vitamin D intake multiplier of juice when comparing the "low carrier intake" with the "high carrier intake" scenario, which is due to the fact that the $5^{\text {th }}$ percentile of juice consumers is near $0 \mathrm{~g}$ per day. Most resistant against a change of the scenario is bread, which is due to the fact that the spread between low bread and high bread consumption is smaller than with any other considered carrier.

\section{Discussion}

We compared the conventional approach of constant food fortification with a new one that takes into account seasonal variations of $25(\mathrm{OH}) \mathrm{D}$ concentrations. To our knowledge this is the first model that is able to find a fortification level, which is needed to either lift an 


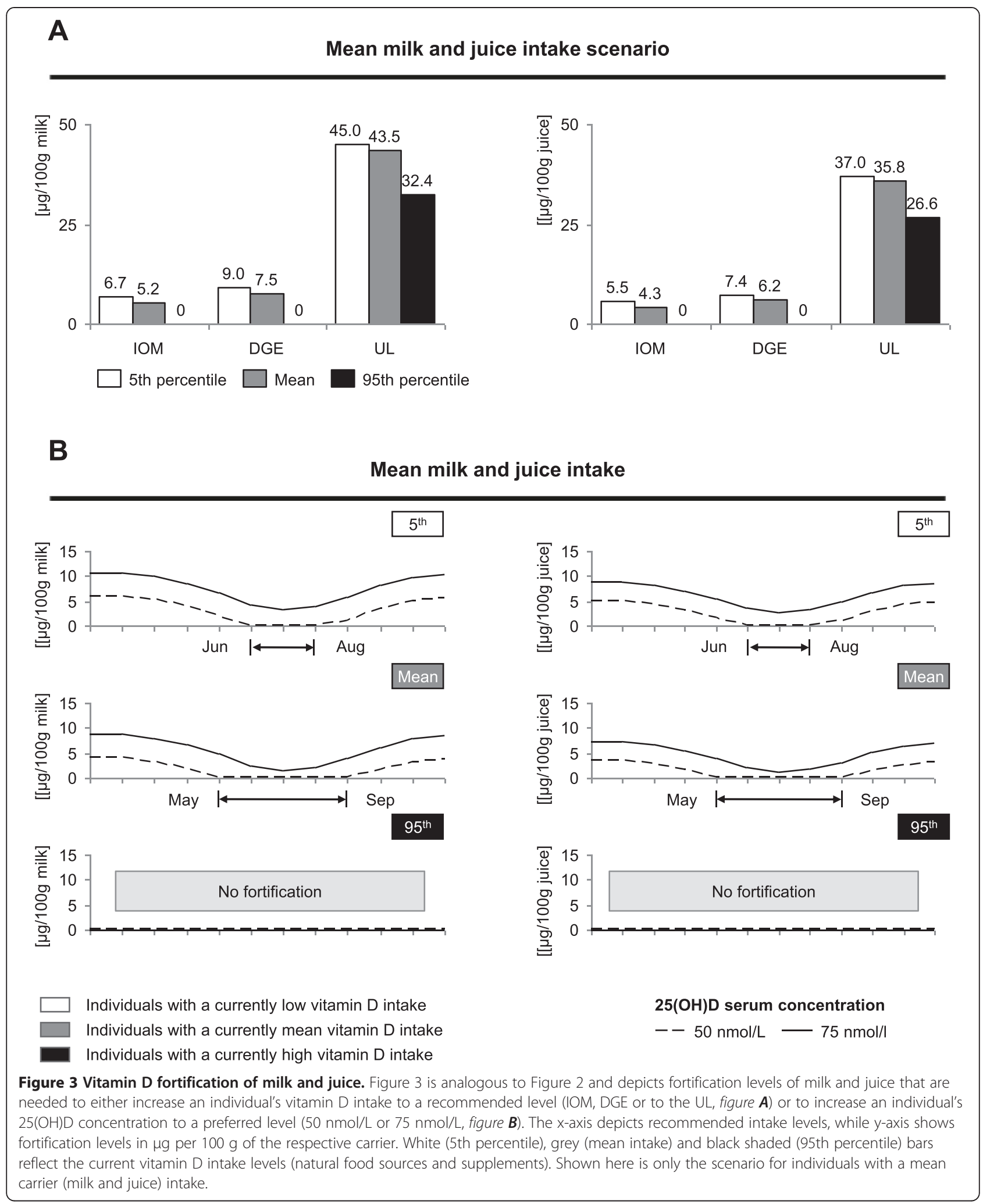

average individual of the German population to a certain predefined $25(\mathrm{OH}) \mathrm{D}$ serum concentration or to raise the intake of an individual to a recommended intake. For means of risk assessments, this model considers several scenarios to estimate upper, mean and lower fortification levels for individuals with different intake. The novelty 


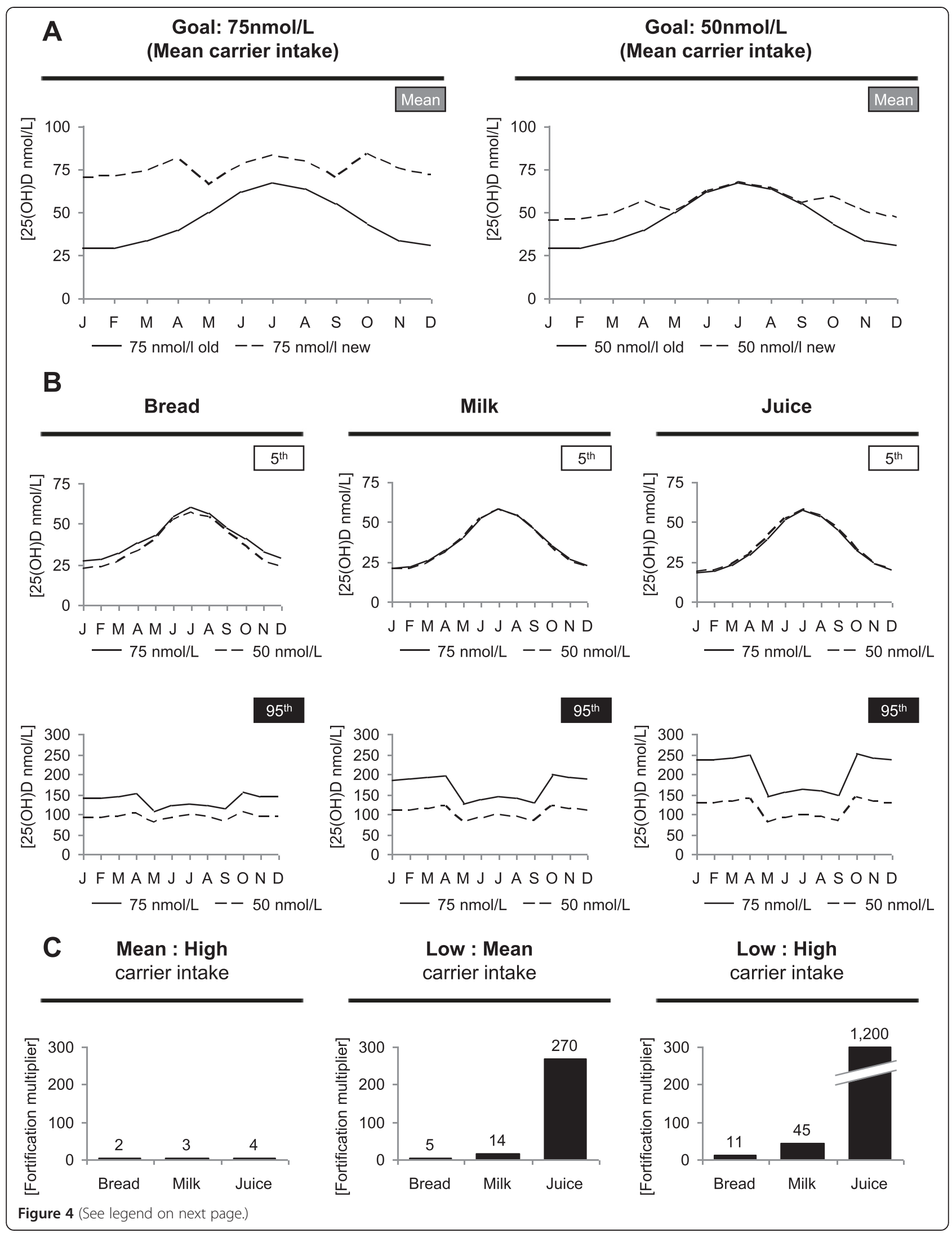


(See figure on previous page.)

Figure 4 Effect of food fortification on $\mathbf{2 5}(\mathrm{OH}) \mathrm{D}$ concentrations and risk considerations. A. Modeled effect of vitamin $\mathrm{D}$ food fortification on $25(\mathrm{OH}) \mathrm{D}$ concentrations. Portrayed is only the scenario of individuals with mean intake of vitamin D and the carrier product. The $x$-axis depicts varying fortification levels throughout the year, while the $y$-axis shows resulting $25(\mathrm{OH}) \mathrm{D}$ levels due to intake of vitamin $\mathrm{D}$ fortified food. The dotted line shows the effect of food fortification when aiming to level $25(\mathrm{OH}) \mathrm{D}$ concentrations at a certain value and the solid line shows $25(\mathrm{OH})$ D concentrations without food fortification. The left graph shows the $75 \mathrm{nmol} / \mathrm{L}$ goal, while the right graphs shows the $50 \mathrm{nmol} / \mathrm{L}$ goal. B. Effect of fortification on people with extreme dietary intake of vitamin D and the carrier product. Driving factors for these extreme estimates are high vitamin D intake (95th percentile) and high fortified foodstuff consumption (95th percentile) for the UL as well as low vitamin D intake (5th percentile) and low fortified foodstuff consumption (5th percentile) for the lower limit. Here, fortification levels are based on average carrier intake. The $x$ - and $y$-axis are defined as in part A. The dotted line belongs to individuals who tend to reach a $25(\mathrm{OH}) \mathrm{D}$ concentration of $50 \mathrm{nmol} / \mathrm{L}$ and the solid line belongs to the $75 \mathrm{nmol} / \mathrm{L}$ goal. The three columns represent risk assessment for bread, milk, and juice. C. Comparison of effects of different vitamin D fortified carrier intake on vitamin D intake. Bars show, how much more vitamin D an individual from a certain carrier intake percentile would invest in comparison to another individual. Compared here are low (5th percentile) with mean and high (95th percentile) carrier intake. The x-axis shows different carrier products, while the $y$-axis represents multiplication factor of vitamin D intake due to vitamin $D$ fortified food.

of the model in hand is based on the fact that it considers $25(\mathrm{OH}) \mathrm{D}$ serum concentrations rather than only intake recommendations and thus aims to level the $25(\mathrm{OH}) \mathrm{D}$ level throughout the year. Our model is programmed in a way that it can be easily adapted to all countries and all vitamin D carriers as long as input parameters are available for respective nations. Although the fortification model is based on simple mathematics, some aspects of the method of the model (4.1), the assumptions and input parameter (4.2) as well as the results (4.3) remain up for discussion and have to be further validated.

\section{The method of the model}

Our approach is different to previously published models from Rasmussen et al. [29], Flynn et al. [28] or Hirvonen et al. [30] in two ways. First, these models add a specific level of vitamin D per $100 \mathrm{kcal}$. Our model adds a specific level of vitamin D per $100 \mathrm{~g}$ of food, but also considers intake of the German population. Due to the combination of intake in gram and fortification levels in vitamin $\mathrm{D}$ per $100 \mathrm{~g}$, the calculation results in a similar logical approach, as our model is likewise able to define fortification levels for people with low, mean or high vitamin D intake. Second, our model not only considers fortification levels to meet certain intake levels, but also takes into account seasonal variations of 25(OH)D levels due to sun exposure. When making risk assessments, the second reason might be considered a shortcoming of our approach, as vitamin D synthesis in the skin may override the effects of nutritional and supplemental intake [35-37]. It could be thus raised to question, whether upper limit considerations are meaningful in the second approach. Opinions are divided concerning the contribution of sunlight as influencing factor for $25(\mathrm{OH}) \mathrm{D}$ serum concentrations. Diffey et al. [35] state that the sun may make up to $56 \%$ percent during summer times, while Shariari et al. [36] report that sun may contribute to vitamin D concentrations by more than $90 \%$. As only average sun exposure habits are available as input parameter for Germany, risk assessment statements in the seasonal variations approach may be put up for debate.

\section{The assumptions and input parameter}

Our model is based on a set of input parameter, see Table 1. While some parameters such as recommended intake levels are non-country specific, some parameters are, e.g. foodstuff consumption. When adapting our model to other countries the availability of these country specific parameters are a key prerequisite. Nevertheless, data availability might be a challenge in some countries.

We made every effort to refrain from input assumptions wherever possible. Nonetheless, an element of uncertainty remains the conversion factors of fortified food. In our model we used the systematic review of O'Donnell et al. [33] that determines the effects of vitamin $\mathrm{D}$-fortified foods on serum 25-hydroxyvitamin D $25(\mathrm{OH}) \mathrm{D}$ concentrations, because the carrier products assessed in O'Donnell's study match the vitamin D carrier portfolio chosen in our study. Yet these conversion factors have been subject of various discussions. Other researchers such as Vieth [38] claim that the conversion factor is lower at around $0.5-1.5 \mathrm{nmol} / \mathrm{L}$ per $1 \mu \mathrm{g}$ vitamin $\mathrm{D}$. However, our model is designed in a way that recalculation based on adapted input parameters, e.g. a lower conversion factor, can easily be performed.

\section{The results}

The results of our fortification model (see example calculation in chapter "results"), stating that an average individual needs approximately $23.7 \mu \mathrm{g}$ a day to reach a concentration of $75 \mathrm{nmol} / \mathrm{L}$, are in line with other observations $[7,11,24,39-44]$. Other publications are of similar statements, proposing $25 \mu \mathrm{g}$ to obtain an adequate serum $25(\mathrm{OH}) \mathrm{D}$ in the absence of UVB irradiance [45] or to raise the level by up to $25 \mathrm{nmol} / \mathrm{L}$ [46], which is comparable to our results. However the intake needed per day to reach a concentration of $75 \mathrm{nmol} / \mathrm{L}$ remains 
controversial since other publications suggest required intake levels of $40 \mu \mathrm{g}$ per day and higher $[47,48]$. Furthermore it is important to note that determining fortification levels based on an average individual's behavior implies that only a certain proportion of the entire population reaches the desired serum concentrations. If the goal is to lift the serum concentration of almost the entire population to a desired level, fortification levels have to be set much higher. However, in this case risk implications gain in importance.

Concerning food products to be fortified, one can argue, whether bread is a suitable carrier for vitamin D as there are only few, but promising experiences [49,50]. However from a nutritional point of view in Germany, bread makes sense in a couple of dimensions. Bread is a basic and a perishable foodstuff in Germany and it is the only food that does not show a consumption decline in the elderly population [34], which is of special importance to prevent osteoporosis. All age categories and all social classes consume bread and the difference between mean intake and the $95^{\text {th }}$ percentile is low compared to other potential vitamin D carriers [34]. This makes the amount of vitamin D intake through fortified foodstuff controllable. Additionally, bread is not a peak product such as juice (frequently consumed during some seasons, like summer time) that could potentially boost vitamin D concentrations to a maximum due to increased intake [34]. Hirvonen et al. [30] also show that bread is an efficient vitamin $\mathrm{D}$ carrier when looking for a solution to reduce the proportion of people with low vitamin D intake and which is safe in avoiding the risk of exceeding the UL. Still it remains open, whether vitamin $\mathrm{D}$ fortified bread alone can be the solution to alleviate vitamin $\mathrm{D}$ deficiency in Germany, as some studies show that food fortification with vitamin $\mathrm{D}$ is more efficient when a wide variety of foods are fortified with a low concentration [30,51]. The risk of overdose is higher for those, who consume larger quantities of certain foods, when only some foodstuff is fortified with high vitamin D concentrations [30]. The more food is fortified with lower concentration, the less likely is overdosing, as nobody can consume high quantities of all foodstuff that is fortified [30]. This is also in line with Välimäki and co-workers [51]. Considering the two other proposed foodstuffs to be fortified, milk as well as juices are common carriers for vitamin D [52-56], which however does not necessarily make these products suitable for fortification in Germany. A reason against milk and juice as carriers is the fact that the quantity spread of consumption for these foodstuffs is rather high [34]. In Finland, for example, this holds true for young women, who are not reached by the current milk fortification policy [57].

Bottom estimates $\left(5^{\text {th }}\right.$ percentile) in Figure $4 \mathrm{~B}$ shows almost no difference for milk and juice, as the $5^{\text {th }}$ percentile almost consumes nothing of those carrier products. This does not hold true for bread as even the $5^{\text {th }}$ percentile consumes at least some bread. Top estimate $\left(95^{\text {th }}\right.$ percentile), reflects the quantity spread in consumption habits, especially for milk and juice. This is subsequently reflected in massive $25(\mathrm{OH}) \mathrm{D}$ concentration increase. One has to mention that these extreme estimates reflect very unlikely scenarios. However, these estimates are useful for risk considerations as they represent the maximum $25(\mathrm{OH}) \mathrm{D}$ concentration increase.

Regardless of the fortification strategy and its potential beneficial impact on the health of the general population, one has to keep in mind two things. First, food fortification per se is not allowed in Germany. There are only few exemptions allowed for general fortification. Among them are margarine, blended fat products as well as dietary food products. Second, vitamin D food fortification poses the risk of a vitamin D intoxication, though it appears to have been caused by excessive vitamin $\mathrm{D}$ fortification of dairy milk [58-60]. Furthermore, intoxication is not the only risk, which might go in hand with vitamin $\mathrm{D}$ food fortification. Although the therapeutic window for a safe supplementation of vitamin D is extremely wide, some groups could be at risk. The body regulates the biologic activation of cholecalciferol through control of $1 \alpha$-hydroxylase activity [22]. This, however, does not apply for the safe supplementation of the active hormone (calcitriol) for example for people with chronic kidney disease, as the therapeutic window is relatively small here [61].

\section{Conclusions}

We compared the conventional approach of constant food fortification with a new strategy that takes into account seasonal variations of $25(\mathrm{OH}) \mathrm{D}$ concentrations. We managed to show that bread as carrier product may be a suitable base. In terms of risk management, however, bread alone is probably not sufficient, as the risk of overdose with a single fortified product is higher than the risk with several fortified carriers [30,51]. Our model is programmed in a way that it can be easily adapted to all countries and all vitamin D carriers as long as input parameters are available for respective nations. To our knowledge, our model with its approach is unique and may help many countries, where the population is prone to vitamin $\mathrm{D}$ deficiency and which are searching for a strategy to improve the vitamin D status of their population to realize associated benefits [62]. General vitamin D intake and respectively $25(\mathrm{OH}) \mathrm{D}$ concentrations of the German population is low. A possible reason might be that food fortification is still prohibited in Germany. With this novel model in hand, it is possible to conceive vitamin $\mathrm{D}$ fortification strategies for different foodstuffs and model its impact on $25(\mathrm{OH}) \mathrm{D}$ concentrations. We propose to critically discuss the strategy of constant food 
fortification and show considerations for a seasonal variation of food fortification to balance $25(\mathrm{OH}) \mathrm{D}$ concentrations on an certain level.

\section{Abbreviations \\ DGE: German nutrition society (Deutsche Gesellschaft für Ernährung): \\ IOM: Institute of Medicine; RI: Recommended intake; UL: Upper limits.}

\section{Competing interests}

The authors declare that they have no competing interests.

\section{Authors' contributions}

All authors contributed sufficiently to our study. JB designed research, conducted research, provided essential materials or information, analyzed data or performed statistical analysis and wrote the paper. AS provided essential information to this study and wrote the paper. MA and Al provided essential information to this study. FB participated in the design and coordination of the study and had primary responsibility for final content. JB and AS contributed equally to this study and therefore share first authorship. All authors read and approved the final manuscript.

\section{Acknowledgements}

The authors thank Dr. Scheidt-Nave, Dr. Mensink as well as Dr. Hintzpeter for their helpful comments and critical discussions.

\section{Author details}

'Department of Osteology and Biomechanics, University Medical Center Hamburg-Eppendorf, Martinistraße 52, D-20246 Hamburg, Germany. ${ }^{2}$ Institute of Orthopaedic Research and Biomechanics, Ulm University, Helmholtzstraße 14, D-89081 Ulm, Germany.

Received: 26 July 2013 Accepted: 18 November 2013

Published: 21 November 2013

\section{References}

1. Linseisen J, Bechthold A, Bischoff-Ferrari HA, Hintzpeter B, Leschik-Bonnet E, Reichrath J, Stehle P, Volkert D, Wolfram GAZ: Vitamin D und Prävention ausgewählter chronischer Krankheiten - Stellungnahme. DGE 2011. www.dge.de.

2. Melamed ML, Michos ED, Post W, Astor B: 25-Hydroxyvitamin D levels and the risk of mortality in the general population. Arch Intern Med 2008, 168(15):1629-1637.

3. Ahonen MH, Tenkanen L, Teppo L, Hakama M, Tuohimaa P: Prostate cancer risk and prediagnostic serum 25-hydroxyvitamin D levels (Finland). Cancer Causes Control 2000, 11(9):847-852.

4. Berwick M, Armstrong BK, Ben-Porat L, Fine J, Kricker A, Eberle C, Barnhill R: Sun exposure and mortality from melanoma. J Natl Cancer Inst 2005, 97(3):195-199.

5. Chang ET, Smedby KE, Hjalgrim H, Porwit-MacDonald A, Roos G, Glimelius B, Adami H-O: Family history of hematopoietic malignancy and risk of lymphoma. J Natl Cancer Inst 2005, 97(19):1466-1474.

6. Feskanich D, Ma J, Fuchs CS, Kirkner GJ, Hankinson SE, Hollis BW, Giovannucci EL: Plasma vitamin D metabolites and risk of colorectal cancer in women. Cancer Epidemiol Biomarkers Prev 2004, 13(9):1502-1508.

7. Garland CF, Garland FC, Gorham ED, Lipkin M, Newmark H, Mohr SB, Holick MF: The role of vitamin D in cancer prevention. Am J Public Health 2006, 96(2):252-261.

8. Giovannucci E: The epidemiology of vitamin $\mathrm{D}$ and colorectal cancer: recent findings. Curr Opin Gastroenterol 2006, 22(1):24-29.

9. Giovannucci E, Liu Y, Rimm EB, Hollis BW, Fuchs CS, Stampfer MJ, Willett WC: Prospective study of predictors of vitamin D status and cancer incidence and mortality in men. J Natl Cancer Inst 2006, 98(7):451-459.

10. Gorham ED, Garland CF, Garland FC, Grant WB, Mohr SB, Lipkin M, Newmark HL, Giovannucci E, Wei M, Holick MF: Vitamin D and prevention of colorectal cancer. J Steroid Biochem Mol Biol 2005, 97(1-2):179-194.

11. Holick MF: Calcium plus vitamin D and the risk of colorectal cancer. $N$ Engl J Med 2006, 354(21):2287-2288.

12. Luscombe CJ, Fryer AA, French ME, Liu S, Saxby MF, Jones PW, Strange RC: Exposure to ultraviolet radiation: association with susceptibility and age at presentation with prostate cancer. Lancet 2001, 358(9282):641-642.
13. Chiu KC, Chu A, Go VLW, Saad MF: Hypovitaminosis D is associated with insulin resistance and $\beta$ cell dysfunction. Am J Clin Nutr 2004, 79(5):820-825.

14. Hypponen $E$, Läärä $E$, Reunanen $A$, Järvelin $M-R$, Virtanen $S M$ : Intake of vitamin D and risk of type 1 diabetes: A birth-cohort study. Lancet 2001, 358(9292):1500-1503.

15. Pittas AG, Dawson-Hughes B, Li T, van Dam RM, Willett WC, Manson JE, Hu FB: Vitamin D and calcium intake in relation to type 2 diabetes in women. Diabetes Care 2006, 29(3):650-656.

16. Holick MF: Vitamin D deficiency. N Engl J Med 2007, 357(3):266-281.

17. Annweiler C, Schott AM, Rolland Y, Blain H, Herrmann FR, Beauchet O: Dietary intake of vitamin $\mathrm{D}$ and cognition in older women. Neurology 2010, 75(20):1810-1816.

18. Cannell JJ, Hollis BW, Sorenson MB, Taft TN, Anderson JJB: Athletic Performance and Vitamin D. Med Sci Sports Exerc 2009, 41(5):1102-1110.

19. Cantorna MT, Zhu Y, Froicu M, Wittke A: Vitamin D status, 1,25dihydroxyvitamin D3, and the immune system. Am J Clin Nutr 2004, 80(6):1717S-1720S

20. Zittermann A: Vitamin D and disease prevention with special reference to cardiovascular disease. Prog Biophys Mol Biol 2006, 92(1):39-48.

21. Ponsonby $A-L, M c M i c h a e l ~ A$, van der Mei I: Ultraviolet radiation and autoimmune disease: insights from epidemiological research. Toxicology 2002, 181-182:71-78.

22. Hathcock JN, Shao A, Vieth R, Heaney R: Risk assessment for vitamin D. Am J Clin Nutr 2007, 85(1):6-18.

23. von Domarus C, Brown J, Barvencik F, Amling M, Pogoda P: How much vitamin D do we need for skeletal health? Clin Orthop Relat Res 2011, 469(11):1-7.

24. Bischoff-Ferrari HA, Giovannucci E, Willett WC, Dietrich T, Dawson-Hughes B: Estimation of optimal serum concentrations of 25-hydroxyvitamin $D$ for multiple health outcomes. Am J Clin Nutr 2006, 84(1):18-28.

25. Hintzpeter B, Scheidt-Nave C, Muller MJ, Schenk L, Mensink GBM: Higher prevalence of vitamin $D$ deficiency is associated with immigrant background among children and adolescents in Germany. J Nutr 2008, 138(8):1482-1490.

26. Hintzpeter B, Mensink GBM, Thierfelder W, Muller MJ, Scheidt-Nave C: Vitamin D status and health correlates among German adults. Eur J Clin Nutr 2008, 62(9):1079-1089.

27. Brown J, Ignatius A, Amling M, Barvencik F: New perspectives on vitamin D sources in Germany based on a novel mathematical bottom-up model of 25(OH)D serum concentrations. Eur J Nutr 2013, 52(7):1733-1742.

28. Flynn A, Moreiras O, Stehle P, Fletcher RJ, Müller DJG, Rolland V: Vitamins and minerals: A model for safe addition to foods. Eur J Nutr 2003, 42(2):118-130.

29. Rasmussen $S$, Andersen N, Dragsted L, Larsen J: A safe strategy for addition of vitamins and minerals to foods. Eur J Nutr 2006, 45(3):123-135

30. Hirvonen T, Sinkko H, Valsta L, Hannila M-L, Pietinen P: Development of a model for optimal food fortification: Vitamin $D$ among adults in Finland. Eur J Nutr 2007, 46(5):264-270.

31. Ross AC, Manson JE, Abrams SA, Aloia JF, Brannon PM, Clinton SK, Durazo-Arvizu RA, Gallagher JC, Gallo RL, Jones G, et al: The 2011 report on dietary reference intakes for calcium and vitamin $D$ from the Institute of Medicine: What clinicians need to know. J Clin Endocrinol Metab 2011, 96(1):53-58

32. DGE (Deutsche Gesellschaft für Ernährung - German Nutrition Society): New reference values for vitamin D. Ann Nutr Metab 2012, 60(4):241-246.

33. O'Donnell S, Cranney A, Horsley T, Weiler HA, Atkinson SA, Hanley DA, Ooi DS, Ward L, Barrowman N, Fang M, et al: Efficacy of food fortification on serum 25-hydroxyvitamin $D$ concentrations: Systematic review. Am J Clin Nutr 2008, 88(6):1528-1534.

34. Max Rubner-Institut (MRI) - Bundesministerium für Ernährung LuV: National Nutritional Survey II - Part 2. [http://www.bmelv.de/SharedDocs/Downloads/ Ernaehrung/NVS_ErgebnisberichtTeil2.pdf?__blob=publicationFile]

35. Diffey BL: Modelling the seasonal variation of vitamin D due to sun exposure. Br J Dermatol 2010, 162(6):1342-1348.

36. Shahriari M, Kerr PE, Slade K, Grant-Kels JE: Vitamin D and the skin. Clin Dermatol 2010, 28(6):663-668.

37. Rodriguez Sangrador M, Beltran de Miguel B, Cuadrado Vives C, Moreiras Tuny O: Influencia de la exposición solar y la dieta en el estado nutricional de vitamina $D$ en adolescentes españolas: estudio de los cinco países (Proyecto OPTIFORD). Nutr Hosp 2007, 25:755-762. 
38. Vieth R: The pharmacology of Vitamin D. In Vitamin D. 3rd edition. Edited by Feldman D. New York: Elsevier; 2011.

39. Holick MF: High prevalence of vitamin D inadequacy and implications for health. Mayo Clin Proc 2006, 81(3):353-373.

40. Holick MF: Vitamin D: Extraskeletal health. J Clin Endocrinol Metab 2010, 39(2):381-400

41. Giovannucci $E$ : The epidemiology of vitamin $D$ and cancer incidence and mortality. Cancer Causes Control 2005, 16(2):83-95.

42. Tangpricha V, Koutkia P, Rieke SM, Chen TC, Perez AA, Holick MF: Fortification of orange juice with vitamin D: a novel approach for enhancing vitamin D nutritional health. Am J Clin Nutr 2003, 77(6):1478-1483.

43. Vieth $\mathrm{R}$ : Why the optimal requirement for Vitamin D3 is probably much higher than what is officially recommended for adults. J Steroid Biochem 2004, 89-90:575-579.

44. Vieth R, Chan P-CR, MacFarlane GD: Efficacy and safety of vitamin D3 intake exceeding the lowest observed adverse effect level. Am J Clin Nutr 2001, 73(2):288-294.

45. Grant WB, Garland CF, Holick MF: Comparisons of estimated economic burdens due to insufficient solar ultraviolet irradiance and vitamin D and excess solar UV irradiance for the United States. Photochem Photobiol 2005, 81(6):1276-1286.

46. Grant WB, Juzeniene A, Moan JE: Health benefit of increased serum 25 $(\mathrm{OH}) \mathrm{D}$ levels from oral intake and ultraviolet-B irradiance in the Nordic countries. Scand J Public Health 2011, 39(1):70-78.

47. Heaney RP, Davies KM, Chen TC, Holick MF, Barger-Lux MJ: Human serum 25-hydroxycholecalciferol response to extended oral dosing with cholecalciferol. Am J Clin Nutr 2003, 77(1):204-210.

48. Gallagher JC, Sai A, Templin IIT, Smith L: Dose response to vitamin D supplementation in postmenopausal women: A randomized trial. Ann Intern Med 2012, 156(6):425-437.

49. Natri A-M, Salo P, Vikstedt T, Palssa A, Huttunen M, Kärkkäinen MUM Salovaara H, Piironen V, Jakobsen J, Lamberg-Allardt CJ: Bread fortified with cholecalciferol increases the serum 25-hydroxyvitamin D concentration in women as effectively as a cholecalciferol supplement. J Nutr 2006, 136(1):123-127.

50. Mocanu V, Stitt PA, Costan AR, Voroniuc O, Zbranca E, Luca V, Vieth R: Long-term effects of giving nursing home residents bread fortified with $125 \mu \mathrm{g}$ (5000 IU) vitamin D3 per daily serving. Am J Clin Nutr 2009, 89(4):1132-1137.

51. Valimaki W, Loyttyniemi E, Valimaki MJ: Vitamin D fortification of milk products does not resolve hypovitaminosis D in young Finnish men. Eur J Clin Nutr 2006, 61(4):493-497.

52. Calvo MS, Whiting SJ, Barton CN: Vitamin D fortification in the United States and Canada: Current status and data needs. Am J Clin Nutr 2004, 80(6):1710S-1716S

53. Moore C, Murphy MM, Keast DR, Holick MF: Vitamin D intake in the United States. J Am Diet Assoc 2004, 104(6):980-983.

54. Moore CE, Murphy MM, Holick MF: Vitamin D intakes by children and adults in the United States differ among ethnic groups. J Nutr 2005, 135(10):2478-2485

55. Calvo MS, Whiting SJ, Barton CN: Vitamin D intake: a global perspective of current status. J Nutr 2005, 135(2):310-316.

56. Laaksi IT, Ruohola JPS, Ylikomi TJ, Auvinen A, Haataja RI, Pihlajamaki HK, Tuohimaa PJ: Vitamin D fortification as public health policy: significant improvement in vitamin D status in young Finnish men. Eur J Clin Nutr 2006, 60(8):1035-1038

57. Lehtonen-Veromaa M, Möttönen T, Leino A, Heinonen OJ, Rautava E, Viikari J: Prospective study on food fortification with vitamin D among adolescent females in Finland: minor effects. Br J Nutr 2008, 100(02):418-423.

58. Jacobus $\mathrm{CH}$, Holick MF, Shao Q, Chen TC, Holm IA, Kolodny JM, Fuleihan GE-H, Seely EW: Hypervitaminosis D associated with drinking milk. N Engl J Med 1992, 326(18):1173-1177.

59. Blank S, Scanlon KS, Sinks TH, Lett S, Falk H: An outbreak of hypervitaminosis $D$ associated with the overfortification of milk from a home-delivery dairy. Am J Public Health 1995, 85(5):656-659.
60. Scanlon KS, Blank S, Sinks T, Lett S, Mueller P, Freedman DS, Serdula M, Falk $\mathrm{H}$ : Subclinical health effects in a population exposed to excess vitamin D in milk. Am J Public Health 1995, 85(10):1418-1422.

61. Querfeld U, Mak R: Vitamin D deficiency and toxicity in chronic kidney disease: in search of the therapeutic window. Pediatr Nephrol 2010, 25(12):2413-2430.

62. Zittermann A: The estimated benefits of vitamin D for Germany. Mol Nutr Food Res 2010, 54(8):1164-1171.

doi:10.1186/1475-2891-12-151

Cite this article as: Brown et al:: New perspectives on vitamin D food fortification based on a modeling of $25(\mathrm{OH}) \mathrm{D}$ concentrations. Nutrition Journal 2013 12:151.

\section{Submit your next manuscript to BioMed Central and take full advantage of:}

- Convenient online submission

- Thorough peer review

- No space constraints or color figure charges

- Immediate publication on acceptance

- Inclusion in PubMed, CAS, Scopus and Google Scholar

- Research which is freely available for redistribution

Submit your manuscript at www.biomedcentral.com/submit
C Biomed Central 